\title{
Bio and mineral-N fertilization of Sunflower (Helianthus annuus L.) Grown on Sandy Soil Using ${ }^{15} \mathbf{N}$ Technique
}

M. A. Hekal ${ }^{1}$, A. A. Abdel-Salam ${ }^{2}$, S. M. Soliman' ${ }^{1}$ Y. G. M. Galal ${ }^{1}$, A. A. Moursy ${ }^{1}$ and W. R. Zahra ${ }^{2}$

${ }^{1}$ Soil and Water Research Department, Nuclear Research Center, Atomic Energy Authority, Egypt.

${ }^{2}$ Soil and Water Department, Faculty of Agriculture, Moshtohor, Benha University, Egypt.

Corresponding authors: Mohamed 070806@fagr.bu.edu.eg

\begin{abstract}
Biofertilization using Azotobacter chroococcum $\left(\mathrm{B}_{1}\right)$, Azospirillum brasilense $\left(\mathrm{B}_{2}\right)$ and Bacillus megaterium $\left(\mathrm{B}_{3}\right)$, were assessed vs. Mineral-N fertilization using ammonium sulphate with $2 \%{ }^{15} \mathrm{~N}$ atom excess on sunflower grown on a virgin sand during 2014 summer season. Plants grew for 45 days. The highest plant height $(64.87 \mathrm{~cm})$ with an increase about $93.6 \%$ over the non-fertilized was given by the Azospirillum bacteria combined with the high $\mathrm{N}$ rate $\left(\mathrm{N}_{3} \mathrm{~B}_{2}\right)$. Total chlorophyll ranged from $17.8 \%$ by $\left(\mathrm{N}_{2} \mathrm{~B}_{1}\right)$ to $34.9 \%$ by $\left(\mathrm{N}_{3} \mathrm{~B}_{0}\right)$. The highest dry matter yield of $44.20 \mathrm{~kg} \mathrm{ha}^{-1}$ was by $\mathrm{N}_{3} \mathrm{~B}_{0}$. The highest $\mathrm{N}$ uptake was given by plants receiving high $\mathrm{N}$ without biofertilization $\left(\mathrm{N}_{3} \mathrm{~B}_{0}\right)$ with an increase $141.4 \%$. The highest fertilizer $\mathrm{N}$ recovery of $18.45 \%$ was by high $\mathrm{N}$ without biofertilization $\left(\mathrm{N}_{3} \mathrm{~B}_{0}\right)$ with an increase $99.7 \%$.
\end{abstract}

Keywords: $\mathrm{N}$ and Biofertilization, Fertilizer $\mathrm{N}$ recovery, ${ }^{15} \mathrm{~N}$-Isotope dilution, Sunflower.

\section{Introduction}

Sunflower (Helianthus annuus L.) is an important edible vegetable oil that ranks the fourth after soybean, palm oil and canola as a source of edible oil in the world (USDA 2008). In Egypt, the cultivated area of sunflower is limited in Nile Valley and the delta due to the competition with other strategic summer crops. However, it could be cultivated on newly reclaimed soils in the desert area, which represents 96\% of Egypt total area (El-Sayed, 2012).

Biofertilizers are organic products containing specific micro-organisms in concentrated forms, derived from the soil root zone (Rhizosphere) (Mishra and Dadhich, 2010). They are considered as an important environment friendly sustainable agricultural practices, with low cost inputs; mainly including nitrogen fixing bacteria (Azotobacter $s p$, Azospirillum $s p$ etc.) and phosphate solubilizing bacteria (Bacillus megtherium) (Sharma and Namdeo, 1999). The beneficial effect of biofertilizers inoculation on sunflower has been reported by several investigators. The obtained results by Keshta and ElKholy (1994) indicated that the application of biofertilizers as a source of $\mathrm{N}_{2}$ fixing bacteria on sunflower increased plant height, total chlorophyll, dry matter yield and $\mathrm{N}$ uptake.

Nitrogen is one of the most important nutrients to plant growth (Li et al., 2015). Plant need huge amount of nitrogen to form protein and nucleic acids. Usually $\mathrm{N}$ is consumed and supplied in the chemical form (Mohamed, 2003). The effect of mineral and organic fertilizers on sunflower was widely investigated (Diacono et al., 2013 and Obour et al., 2017).

Osman and Awed (2010) in their study on sunflower showed that, increasing nitrogen level from $72 \mathrm{~kg}$ to $144 \mathrm{~kg} \mathrm{~N} \mathrm{ha}^{-1}$ significantly increased all yield components.
This work aimed at tracing the contribution of bacterial inoculants and $\mathrm{N}$ fertilization rates on sunflower plants grown on poor fertile sand soil to recognize the best management combinations.

\section{Materials and Methods}

A field experiment to assess biofertilization and mineral fertilization on Sunflower (Helianthus annuus L.) was conducted at the Experimental Field of Soil and Water Research Department, Nuclear Research Center, Atomic Energy Authority, Abu-Zaable, Egypt during 2014 under drip irrigation system. The soil was sand. A randomized complete block design was used in the experiment with two factors. Factor N fertilization $(\mathrm{N})$ : with 4 treatments: unfertilized $\left(\mathrm{N}_{0}\right), 105 \mathrm{~kg} \mathrm{~N} \mathrm{ha}^{-1}\left(\mathrm{~N}_{1}\right), 140 \mathrm{~kg} \mathrm{~N}^{-1}\left(\mathrm{~N}_{2}\right)$ and 175 $\mathrm{kg} \mathrm{N} \mathrm{ha-1}\left(\mathrm{N}_{3}\right)$. Factor biofertilization (B): with 4 treatments: non-fertilized $\left(\mathrm{B}_{0}\right)$, fertilization with Azotobacter chroococcum $\left(\mathrm{B}_{1}\right)$, fertilization with Azospirillum brasilense $\left(\mathrm{B}_{2}\right)$ and fertilization with Bacillus megaterium $\left(\mathrm{B}_{3}\right)$, where $\mathrm{B}_{1}$ and $\mathrm{B}_{2}$ being free-living $\mathrm{N}_{2}$-fixers and $\mathrm{B}_{3}$ a P-dissolver ; each inoculum obtained from Agriculture Research Center, Giza, Egypt and was mounted on a peat moss carrier. A saccharide solution was used as a material for sticking the inoculants on seed surface three hours before seeding. Seeding was in rows (63 $\mathrm{cm}$ apart) with two seeds per hill $30 \mathrm{~cm}$ between hills. The plot area was $10 \mathrm{~m}^{2}(1.25 \mathrm{~m} \times 8.0 \mathrm{~m})$. The crop exhibited no sign of insect or pest attack or disease incidence; therefore, no protection measures were applied. Compost provided by the Faculty of Agriculture, Moshtohor was used as a basal treatment $\left(21 \mathrm{Mg} \mathrm{ha}^{-1}\right)$ for the experimental field before cultivation (45 days before cultivation). Compost properties are presented in Table 1. Compost analyses were done according to methods cited by Carter and Gregorish (2008). 
Seeds were sown on April 15 $5^{\text {th }}, 2014$ and plants were

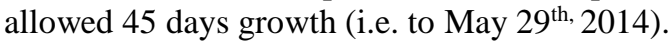

Table 1. Main properties of organic compost used in the study.

\begin{tabular}{|c|c|c|c|c|c|c|}
\hline \multicolumn{7}{|c|}{ Nutrients ' $\mathrm{mgkg}^{-1}$ ', organic matter, ash, moisture $\left(\mathrm{g} \mathrm{kg}^{-1}\right), \mathrm{pH}, \mathrm{EC}$ and $\mathrm{C} / \mathrm{N}$ ratio of compost } \\
\hline $\mathbf{N}$ & $\mathbf{P}$ & $\mathbf{K}$ & Fe & Mn & $\mathbf{Z n}$ & $\mathbf{C u}$ \\
\hline 21.0 & 10.3 & 21.1 & 4.1 & 0.5 & 0.3 & 0.2 \\
\hline \multirow{2}{*}{$\begin{array}{c}\mathbf{P h} \\
(1: 2.5)\end{array}$} & $\begin{array}{c}\text { EC } \\
(1: 2.5)\end{array}$ & $\begin{array}{c}\text { Organic } \\
\text { matter }\end{array}$ & Ash & $\begin{array}{c}\text { Organic } \\
\text { carbon }\end{array}$ & \multirow[t]{2}{*}{$\mathrm{C} / \mathrm{N}$ ratio } & \multirow{2}{*}{$\begin{array}{c}\text { Moisture } \\
\text { (g kg) }\end{array}$} \\
\hline & $\left(\mathrm{dS} \mathrm{m} \mathrm{m}^{-1}\right)$ & & $\mathrm{g} \mathrm{kg}^{-1}$ & & & \\
\hline 7.4 & 5.2 & 643 & 332 & 207.0 & 9.9 & 22.6 \\
\hline
\end{tabular}

A micro-plot was allocated where ${ }^{15} \mathrm{~N}$ ammonium sulphate with $2 \%{ }^{15} \mathrm{~N}$ atom excess was used for ${ }^{15} \mathrm{~N}$ isotope assessment. All plots received $\mathrm{P}$, $\mathrm{K}$ and micronutrients as recommended by bulletin of the Ministry of Agriculture and Reclamation. N (as ammonium sulphate, $207 \mathrm{~g} \mathrm{~N} \mathrm{~kg}^{-1}$ ) was applied in two equal splits ( 2 and 4 weeks after sowing).P was at 24 kg P ha-1 (as Ca-superphosphate, $68 \mathrm{~g} \mathrm{P} \mathrm{kg}^{-1}$ ) during soil preparations, while $\mathrm{K}$ was at $25 \mathrm{~kg} \mathrm{~K} \mathrm{ha}^{-1}$ (as Ksulphate, $415 \mathrm{~g} \mathrm{~K} \mathrm{~kg}^{-1}$ ) 4 weeks after sowing. Soil properties (Table 2) were determined according to Carter and Gregorich (2008). Fertilizer N recovery (FNR) was calculated as follows:

$\mathrm{FNR}=\left\{\mathrm{kg} \mathrm{N} \mathrm{ha}^{-1}\right.$ derived from fertilizer $\div \mathrm{kg}$ $\mathrm{N}^{-1}$ fertilizer rate $\}$ x 100

Table 2. Main properties of soil of the experiment.

\begin{tabular}{|c|c|c|c|c|c|}
\hline $\begin{array}{c}\mathbf{p H} \\
(1: 2.5)\end{array}$ & $\begin{array}{c}\mathbf{E C}^{*} \\
\left(\mathrm{dS} \mathrm{m} \mathrm{m}^{-1}\right)\end{array}$ & & & \multicolumn{2}{|c|}{$\begin{array}{c}\text { Organic matter } \\
\left(\mathrm{g} \mathrm{kg}^{-1}\right)\end{array}$} \\
\hline 7.12 & 0.27 & & & & \\
\hline \multicolumn{3}{|c|}{ Available nutrients $* *\left(\mathrm{mg} \mathrm{kg}^{-1}\right)$} & \multicolumn{3}{|c|}{ Total nutrients $\left(\mathrm{g} \mathrm{kg}^{-1}\right)$} \\
\hline $\mathbf{K}$ & $\mathbf{P}$ & $\mathbf{N}$ & $\mathbf{K}$ & $\mathbf{P}$ & $\mathbf{N}$ \\
\hline 1.0 & 0.1 & 0.3 & 0.2 & 2.0 & 5.0 \\
\hline \multicolumn{6}{|c|}{ Particle size distribution (\%) } \\
\hline Clay & Silt & & & & \\
\hline 0.0 & 2.0 & & & & \\
\hline
\end{tabular}

* In paste extract. **Extracts of: $\mathrm{KCl}$ for $\mathrm{N} ; \mathrm{NaHCO}_{3}$ for $\mathrm{P} ; \mathrm{NH}_{4}$-acetate for $\mathrm{K}$; soil texture according to the International Soil Texture Triangle (Moeys 2014)

Samples of plants were analyzed according to methods cited by Estefan et al. (2013). ${ }^{15} \mathrm{~N}$ analysis was carried out using automated emission spectrometer (Fischer NOI-6 PC).The portion of nitrogen derived from fertilizer (\%Ndff) present in the relevant plant was calculated in view of the ${ }^{15} \mathrm{~N}$ atom excess $\left({ }^{15} \mathrm{~N}\right.$ a.e.) in materials (IAEA, 2008). The equation is as follows:

$\%$ Ndff $=\left({ }^{15} \mathrm{~N}\right.$ a.e. in plant $\div{ }^{15} \mathrm{~N}$ a.e. in fertilizer $) \mathrm{x}$ 100

$\left(\mathrm{kg} \mathrm{ha}^{-1}\right) \times 100$

$\%$ FNR $=$ Ndff $\left(\mathrm{kg} \mathrm{ha}^{-1}\right) /$ rate of applied $\mathrm{N}$

\section{Results and Discussion}

\section{Plant height:}

The lowest height of $33.5 \mathrm{~cm}$ was given by the untreated $\mathrm{B}_{0} \mathrm{~N}_{0}$ plants while the highest of $64.9 \mathrm{~cm}$ was given by those of $\mathrm{B}_{2} \mathrm{~N}_{3}$ which received
Azospirillum brasilense bacteria and the high $\mathrm{N}$ rate, with a relative increase of $93.6 \%$. The main effect of biofertilization shows averages of 3.40, 1.63 and $12.68 \%$ due to $\mathrm{B}_{1}, \mathrm{~B}_{2}$ and $\mathrm{B}_{3}$, respectively (Table 3 ). Biofertilization showed positive effect only in presence of mineral $\mathrm{N}$ fertilization. The main effect on mineral $\mathrm{N}$ fertilization shows a pattern of $\mathrm{N}_{2}>\mathrm{N}_{3}>\mathrm{N}_{1}>\mathrm{N}_{0}$ with highest plant height given by $\mathrm{N}_{2}$ followed by $\mathrm{N}_{3}$ then $\mathrm{N}_{1}$ with increases averaging 39.8, 49.3 and $48.4 \%$ due to $\mathrm{N}_{1}, \mathrm{~N}_{2}$ and $\mathrm{N}_{3}$ respectively. Chantal et al. (2018) found that the high N, P and K level gave the highest sunflower plant high with 142.6 $\mathrm{cm}$. These results support those of Mostafa and AboBaker (2010), who reported increased sunflower growth due to higher rate application of nitrogen. Similar experimental results were attained by Shah and Khanday (2005) as well as Sarkar and Mallick (2009). 
Table 3. Response to $\mathrm{N}$ inorganic fertilization and $\mathrm{N}$ or $\mathrm{P}$ biofertilization of sunflower: plant height after 45 day $(\mathrm{cm})$

\begin{tabular}{cccccc}
\hline $\begin{array}{c}\text { Inorganic } \\
\text { Fertilization } \\
(\mathbf{N})\end{array}$ & $\mathbf{B}_{\mathbf{0}}$ & \multicolumn{2}{c}{ Biofertilization $\mathbf{( B )}$} & mean \\
\hline $\mathbf{N}_{\mathbf{0}}$ & 33.50 & $\mathbf{B}_{\mathbf{1}}$ & $\mathbf{B}_{\mathbf{2}}$ & $\mathbf{B}_{3}$ & $\mathbf{3 8 . 6 8}$ \\
$\mathbf{N}_{\mathbf{1}}$ & 52.40 & 34.37 & 31.17 & 55.67 & $\mathbf{5 4 . 0 8}$ \\
$\mathbf{N}_{\mathbf{2}}$ & 62.00 & 53.50 & 52.50 & 57.90 & $\mathbf{5 7 . 7 4}$ \\
$\mathbf{N}_{\mathbf{3}}$ & 51.17 & 58.00 & 53.80 & 57.17 & $\mathbf{5 7 . 4 0}$ \\
mean & $\mathbf{4 9 . 7 7}$ & 59.97 & 64.87 & 53.60 & $\mathbf{5 6 . 0 8}$ \\
\end{tabular}

LSD: $0.05=\mathrm{N}: 0.61 \quad$; B: $0.61 \quad$; NB: 1.21

Notes: $\mathrm{B}_{0}$ : without biofertilization - $\mathrm{B}_{1}$ : Azotobacter; $\mathrm{B}_{2}$ : Azospirillum; $\mathrm{B}_{3}$ : Bacillus megaterium ..... $\mathrm{N}_{0}, \mathrm{~N}_{1}$, $\mathrm{N}_{2}$ and $\mathrm{N}_{3}=0,73.5,98.0$ and $122.5 \mathrm{~kg} \mathrm{~N} \mathrm{ha}^{-1}$ (as ammonium sulphate) respectively.

Total chlorophyll:

Application of $\mathrm{N}$ singly increased the total chlorophyll in plant leaves. Plants receiving $\mathrm{N}$ gave high total chlorophyll in plant leaves (Table 4). The increase in ranged from $17.8 \%$ by $\mathrm{N}_{2} \mathrm{~B}_{1}$ to $34.9 \%$ by $\mathrm{N}_{3} \mathrm{~B}_{0}$. Therefore, high $\mathrm{N}$ gave the highest total chlorophyll indicating a need for high $\mathrm{N}$ fertilization in order to obtain high chlorophyll in plant. In this case, soil should be reached to field capacity most of time to save the micro-organisms from these unsuitable conditions. The main effect on $\mathrm{N}$ fertilization shows a pattern of $\mathrm{N}_{3}>\mathrm{N}_{2}>\mathrm{N}_{1}>\mathrm{N}_{0}$ with highest plant height given by $\mathrm{N}_{3}$ followed by $\mathrm{N}_{2}$ then $\mathrm{N}_{1}$. Increase averaged $30.55,35.12$ and $37.59 \%$ due to $\mathrm{N}_{1}, \mathrm{~N}_{2}$ and $\mathrm{N}_{3}$, respectively. Biofertilization showed positive effect only within absence of $\mathrm{N}$. the main effect of biofertilization shows a decrease averaged 1.36, 3.48 and $2.71 \%$ due to $\mathrm{B}_{1}, \mathrm{~B}_{2}$ and $\mathrm{B}_{3}$, respectively as shown in Table 2 . The chlorophyll amounts were observed with in-creased nitrogen doses. While the value obtained from $30 \mathrm{~g} \mathrm{~N}$ tree $^{-1}$ and $60 \mathrm{~g}$ tree $^{-1}$ doses were higher than the control application, the highest chlorophyll dose was observed in $90 \mathrm{~g} \mathrm{~N}^{\mathrm{N}}$ tree $^{-1}$ dose. While the lowest chlorophyll was found in control, it was followed by the $30 \mathrm{~g} \mathrm{~N}^{-1} \mathrm{tre}^{-1}$ dose and the highest values were observed in the same groups of $60 \mathrm{~g} \mathrm{~N}$ tree ${ }^{-1}$ and $90 \mathrm{~g}$ $\mathrm{N}$ tree $^{-1}$ (Erdinç, 2018). It concluded that total chlorophyll was increased by increasing the rate of nitrogen

Table 4. Response to $\mathrm{N}$ inorganic fertilization and $\mathrm{N}$ or $\mathrm{P}$ biofertilization of sunflower: total chlorophyll after 45-day

\begin{tabular}{|c|c|c|c|c|c|}
\hline \multirow{2}{*}{$\begin{array}{c}\text { Inorganic } \\
\text { Fertilization } \\
\text { (N) }\end{array}$} & \multicolumn{4}{|c|}{ Biofertilization ( B) } & \multirow{2}{*}{ mean } \\
\hline & $\mathbf{B}_{0}$ & $\mathbf{B}_{1}$ & $\mathbf{B}_{2}$ & $\mathbf{B}_{3}$ & \\
\hline $\mathbf{N}_{0}$ & 29.20 & 27.97 & 26.00 & 27.20 & 27.59 \\
\hline $\mathbf{N}_{1}$ & 35.07 & 37.47 & 36.37 & 35.17 & 36.02 \\
\hline $\mathbf{N}_{2}$ & 37.87 & 34.40 & 37.17 & 36.70 & 37.28 \\
\hline $\mathbf{N}_{3}$ & 39.40 & 36.77 & 37.07 & 38.60 & 37.96 \\
\hline mean & 35.38 & 34.90 & 34.15 & 34.42 & \\
\hline $\begin{array}{l}\text { LSD: } 0.05=\mathrm{N}: 0.27 \\
\text { See footnotes of Tab }\end{array}$ & $\begin{array}{l}\text {; B: } 0.27 \\
3\end{array}$ & .54 & & & \\
\hline
\end{tabular}

\section{Dry matter yield:}

The pattern of response (Table 5) was rather similar to that of total chlorophyll. Application of Bacillus Megaterium (singly) under no N application $\left(\mathrm{N}_{0} \mathrm{~B}_{3}\right)$ gave the lowest dry matter yield of $5.53 \mathrm{~kg} \mathrm{ha}^{-}$ 1 , while the highest was $44.20 \mathrm{~kg} \mathrm{ha}^{-1}$ (an increase of $699 \%$, given by the high $\mathrm{N}$ non-biofertilized $\left(\mathrm{N}_{3} \mathrm{~B}_{0}\right)$. The main effect of $\mathrm{N}$ fertilization shows a pattern of $\mathrm{N}_{3}>\mathrm{N}_{1}>\mathrm{N}_{2}>\mathrm{N}_{0}$ with highest plant height given by $\mathrm{N}_{3}$ followed by $\mathrm{N}_{1}$ then $\mathrm{N}_{2}$. Increases averaged 91.9, 36.9 and $143.7 \%$ due to $\mathrm{N}_{1}, \mathrm{~N}_{2}$ and $\mathrm{N}_{3}$, respectively. Such a pattern of response was particularly evident under conditions of no biofertilization or under the Pdissolver Bacillus Megaterium. Nasim et al. (2011) observed that, with increasing $\mathrm{N}$ rate to sunflower, there was an increase in plant growth.Under biofertilization with the $\mathrm{N}$-fixers there was little or no difference between the inorganic $\mathrm{N}$-applied treatments. The main effect of biofertilization shows no positive response due to biofertilization. There were decreases averaging 35.031 .8 and $31.5 \%$ due to $\mathrm{B}_{1}, \mathrm{~B}_{2}$ and $\mathrm{B}_{3}$, respectively. This shows that the biofertilizer organisms caused a depletion of soil available $\mathrm{N}$ leading to a decrease in plant growth and consequently $\mathrm{N}$ uptake. There should be enough available nutrients in the soil to make biofertilizer microorganisms increase plant growth. 
Table 5. Response to $\mathrm{N}$ inorganic fertilization and $\mathrm{N}$ or $\mathrm{P}$ biofertilization of sunflower: Dry matter yield (kg $\mathrm{ha}^{-1}$ ) in plants 45 -day

\begin{tabular}{cccccc}
\hline $\begin{array}{c}\text { Inorganic } \\
\text { Fertilization } \\
(\mathbf{N})\end{array}$ & $\mathbf{B}_{\mathbf{0}}$ & \multicolumn{2}{c}{ Biofertilization ( B) } & mean \\
\hline $\mathbf{N}_{\mathbf{0}}$ & 19.54 & $\mathbf{B}_{\mathbf{1}}$ & $\mathbf{B}_{\mathbf{2}}$ & $\mathbf{B}_{\mathbf{3}}$ & \\
$\mathbf{N}_{\mathbf{1}}$ & 25.14 & 17.89 & 12.19 & 5.53 & $\mathbf{1 1 . 5 5}$ \\
$\mathbf{N}_{\mathbf{2}}$ & 18.56 & 21.10 & 21.32 & 24.29 & $\mathbf{2 2 . 1 6}$ \\
$\mathbf{N}_{\mathbf{3}}$ & 44.20 & 20.87 & 17.53 & 13.75 & $\mathbf{1 8 . 9 3}$ \\
mean & $\mathbf{2 6 . 8 6}$ & $\mathbf{1 7 . 2 0}$ & $\mathbf{1 8 . 3 3}$ & 29.98 & $\mathbf{2 8 . 1 5}$ \\
\hline
\end{tabular}

LSD: $0.05=\mathrm{N}: 3.93 \quad$; B: $3.93 \quad$; NB: 7.85

See footnotes of Table 3

N uptake

Response of $\mathrm{N}$ uptake resembled that of the yield (Table 6). The lowest $\mathrm{N}$ uptake of $9.72 \mathrm{kgha}^{-1}$ was given by application of Bacillus Megaterium under no $\mathrm{N}$ fertilization $\left(\mathrm{N}_{0} \mathrm{~B}_{3}\right)$, while the highest of $65.36 \mathrm{~kg} \mathrm{ha}^{-1}$ (which surpassed the lowest by $572 \%$ ) was given by the non-biofertilized high $\mathrm{N}\left(\mathrm{N}_{3} \mathrm{~B}_{0}\right)$. The main effect of $\mathrm{N}$ fertilization shows a pattern of $\mathrm{N}_{3}>\mathrm{N}_{1}>\mathrm{N}_{2}>\mathrm{N}_{0}$. Increases averaging 91.9, 36.9 and $143.7 \%$ due to $N_{1}, N_{2}$ and $N_{3}$, respectively. Such a pattern of response was particularly true under conditions of no biofertilization or under the P- dissolver Bacillus Megaterium. Under biofertilization with the N-fixers little or no difference between the inorganic fertilizers was noted. The main effect of biofertilization shows no positive response with the three applied biofertilizers, with all being similar in effect. Dcreases caused by the biofertilizers averaged $35.0,31.8$ and $31.5 \%$ due to $\mathrm{B}_{1}, \mathrm{~B}_{2}$ and $\mathrm{B}_{3}$, respectively. This indicates that the biofertilizer organisms depleted available $\mathrm{N}$ in the soil (which is sand nearly devoid of available $\mathrm{N}$ ). These results agree with those obtained by Ahmed and El-Araby (2012) and Nadeem et al. (2014)

Table 6: Response to $\mathrm{N}$ inorganic fertilization and $\mathrm{N}$ or $\mathrm{P}$ biofertilization of sunflower: $\mathrm{N}$ uptake $\left(\mathrm{g} \mathrm{ha}^{-1}\right)$ in plants 45-day

\begin{tabular}{|c|c|c|c|c|c|}
\hline \multirow{2}{*}{$\begin{array}{l}\text { Inorganic } \\
\text { Fertilization } \\
\text { (N) }\end{array}$} & \multicolumn{4}{|c|}{ Biofertilization ( B) } & \multirow{2}{*}{ mean } \\
\hline & $\mathbf{B}_{\mathbf{0}}$ & $\mathbf{B}_{1}$ & $\mathbf{B}_{2}$ & $\mathbf{B}_{3}$ & \\
\hline $\mathrm{N}_{0}$ & 27.08 & 15.64 & 19.12 & 9.72 & 17.89 \\
\hline $\mathbf{N}_{1}$ & 41.09 & 33.59 & 33.58 & 38.31 & 36.64 \\
\hline $\mathbf{N}_{2}$ & 29.19 & 34.45 & 36.44 & 25.85 & 31.48 \\
\hline $\mathbf{N}_{3}$ & 65.36 & 36.47 & 27.21 & 36.52 & 41.39 \\
\hline mean & 40.68 & 30.04 & 29.09 & 27.60 & \\
\hline LSD: 0.05 = N: 2.62 & ; B: 2.62 & ; NB: 5.23 & & & \\
\hline
\end{tabular}

\section{Nitrogen derived from fertilizer (Ndff):}

Ndff (Table 7) was lowest of $9.06 \mathrm{kgha}^{-1}$ given by the medium-N Bacillus Megaterium biofertilized treatment $\left(\mathrm{N}_{2} \mathrm{~B}_{3}\right)$. The highest of 22.61 (surpassing the lowest by $149.6 \%$ ) was given by the high-N nonbiofertilized $\mathrm{N}_{3} \mathrm{~B}_{0}$ treatment. Under condition of no biofertilization or B. Megaterium, the highest Ndff was given by the treatment of highest $\mathrm{N}$ dose. Under biofertilization with the $\mathrm{N}$-fixers the medium $\mathrm{N}$ treatment showed highest Ndff. High Ndff indicates high efficient use of fertilizer N. A combination of biofertilizers such as $\mathrm{N}_{2}$-fixers or P-dissolvers along with the soluble fertilizer $\mathrm{N}$ would enhance the positive effect of $\mathrm{N}$ fertilization (Hekal, 2015).

Table 7. Response to $\mathrm{N}$ inorganic fertilization and $\mathrm{N}$ or $\mathrm{P}$ biofertilization of sunflower: $\mathrm{Ndff}\left(\mathrm{kg} \mathrm{ha}^{-1}\right)$ in plants 45-day

\begin{tabular}{|c|c|c|c|c|c|}
\hline \multirow{2}{*}{$\begin{array}{c}\text { Inorganic } \\
\text { Fertilization } \\
(\mathbf{N})\end{array}$} & \multicolumn{4}{|c|}{ Biofertilization ( B) } & \multirow{2}{*}{ Mean } \\
\hline & $\mathbf{B}_{0}$ & $\mathbf{B}_{1}$ & $\mathbf{B}_{2}$ & $\mathbf{B}_{3}$ & \\
\hline $\mathbf{N}_{1}$ & 13.50 & 7.75 & 9.80 & 12.12 & 10.79 \\
\hline $\mathbf{N}_{2}$ & 9.67 & 15.48 & 16.22 & 9.06 & 12.61 \\
\hline $\mathbf{N}_{3}$ & 22.61 & 13.43 & 11.57 & 16.83 & 16.11 \\
\hline mean & 15.26 & 12.22 & 12.53 & 12.67 & \\
\hline
\end{tabular}

See footnotes of Table 3. Values are averages and no statistical analysis was done.

Fertilizer nitrogen recovery (FNR): 
Fertilizer $\mathrm{N}$ recovery (FNR) represents the portion of $\mathrm{N}$ derived from fertilizer in relation to the rate of applied N. Table 8 shows that the lowest FNR of $9.24 \%$ was obtained in the plants given the medium $\mathrm{N}$ B. Megaterium $\left(\mathrm{N}_{2} \mathrm{~B}_{3}\right)$ and the second lowest of $9.87 \%$ was obtained by the medium $\mathrm{N}$ nonbiofertilized treatment $\left(\mathrm{N}_{2} \mathrm{~B}_{0}\right)$. The highest of $18.45 \%$ (surpassing the lowest by $99.7 \%$ ) was given by the
high-N non-biofertilized $\mathrm{N}_{3} \mathrm{~B}_{0}$ treatment. Under condition of no biofertilization or B. Megaterium, the highest FNR was given by high or low dose of $\mathrm{N}$. Under biofertilization with the $\mathrm{N}$-fixers the medium $\mathrm{N}$ treatment showed highest FNR. The direct method on ${ }^{15} \mathrm{~N}$ add is the most adequate to determine the recovery efficiency of $\mathrm{N}$ derived from fertilizer (Araújo et al., 2018).

Table 8. Response to $\mathrm{N}$ inorganic fertilization and $\mathrm{N}$ or $\mathrm{P}$ biofertilization of sunflower: ${ }^{15} \mathrm{~N}$ recovery $(\%)$ in plants 45-day

\begin{tabular}{cccccc}
\hline Inorganic & \multicolumn{4}{c}{ Biofertilization $(\mathbf{B})$} & Mean \\
\cline { 2 - 5 } Fertilization & $\mathbf{B}_{\mathbf{0}}$ & $\mathbf{B}_{\mathbf{1}}$ & $\mathbf{B}_{\mathbf{2}}$ & $\mathbf{B}_{\mathbf{3}}$ & \\
$\mathbf{N})$ & 18.37 & 10.54 & 13.33 & 16.49 & $\mathbf{1 4 . 6 8}$ \\
$\mathbf{N}_{\mathbf{1}}$ & 9.87 & 15.80 & 16.55 & 9.24 & $\mathbf{1 2 . 8 6}$ \\
$\mathbf{N}_{\mathbf{2}}$ & 18.45 & 10.96 & 9.44 & 13.74 & $\mathbf{1 3 . 1 5}$ \\
$\mathbf{N}_{\mathbf{3}}$ & $\mathbf{1 5 . 5 6}$ & $\mathbf{1 2 . 4 3}$ & $\mathbf{1 3 . 1 1}$ & $\mathbf{1 3 . 1 6}$ & \\
\hline Mean & &
\end{tabular}

See footnotes of Table 2. Values are averages and no statistical analysis was done.

\section{References}

Ahmed, H. F. S. and El-Araby, M. M. I. 2012. Evaluation of the influence of nitrogen fixing, phosphate solubilizing and potash mobilizing biofertilizers on growth, yield, and fatty acid constituents of oil in peanut and sunflower. African J. Biotech. 11(43):10079-10088.

Araújo, E. S., da Silva, B. F., Chieza, E. D, Urquiaga, S., Guerra, J. G. M., Costa, J. R. and Espíndola, J. A. A. 2019. Comparison of $15 \mathrm{~N}$ isotope methods to determine the recovery efficiency of nitrogen from green manure. Pesq. agropec. bras., Brasília 54: e00721

Carter, M. R. and Gregorich, E. G. 2008. Soil sampling and methods of analysis. Canada. Soc. Soil Sci., $2^{\text {nd }}$ Ed.

Chantal, K., Ongor, B. T., Bandushubwenge, D., Soter, N. and Felix, S. 2018. Effects of different nitrogen fertilizer levels on sunflower growth and yield attributes. Pakistan J. Nut. 17(11): 557-562.

Diacono, M., Rubino, P. and Montemurro, F. 2013. Precision nitrogen management of wheat. A review. Agron. Sustain. Dev. 33:219-241.

El-Sayed, L. M. 2012. Determination an optimum cropping pattern for Egypt. M. Sc. Am. Uni. Cairo, Egypt.

Erdinç U.Y.S.A.L. 2018. Effects of Nitrogen Fertilization on the Chlorophyll Content of Apple. Meyve Bilimi Fruit Sci. 5(1):12-17.

Estefan, G., Sommer, R. and Ryan, J. 2013. Methods of soil, plant and water analysis: A manual for the West Asia and North Africa regions. Int. Center Agric. Res.in Dry Areas (ICARDA), $3^{\text {rd }}$ Ed.

Hekal, M.A. 2015. Fertilizer N recovery in sunflower crop and interaction between bio and inorganic fertilization using stable ${ }^{15} \mathrm{~N}$ isotope. M.Sc. Thesis, Fac. of Agric. Benha Univ. Egypt
IAEA 2008. Training course. International Atomic Energy Agency (IAEA) No. 14, Vienna, Austria.

Keshta, M. M. and EL-Kholy, M. H. 1994. Effect of inoculation with $\mathrm{N}_{2}$-fixing bacteria, nitrogen fertilizer and organic manure on sunflower. Proc. Int. Symp. Biolog. $\mathrm{N}_{2-}$ fixation and Crop prod., Cairo, Egypt, 11-13 May:181-187.

Li, S. X., Wang, Z. H., Li, S. Q. and Gao, Y. J. 2015. Effect of nitrogen fertilization under plastic mulched and non-plastic mulched conditions on water use by maize plants in dry bland areas of China. Agric. Water Manag. 162:15-32.

Mishra, B. K. and Dadhich, S. K. 2010. Methodology of nitrogen bio-fertilizer production. J. Adv. Devel. Res. (1): 3-6.

Moeys, J. 2014. The soil texture wizard: R-function for plotting, transforming and exploring soil texture data. Swedish University of Agric. Sci. Uppsala, Sweden.

Mohamed, A. A. E. 2003. Response of sunflower to Phosphorine and Cerealine on growth and yield of soybean (Glycine max L. Merril) crop Res. (Hisar) 17: 160-163.

Mostafa, G. G. and Abo-Baker, A. A. 2010. Effect of bio-and chemical fertilization on growth of sunflower (Helianthus annuus L.) at south valley area. Asian J. Crop Sci. 2(3):137-146.

Nadeem, S. M., Ahmad, M., Zahir, Z. A., Javaid, A. and Ashraf, M. 2014. The role of mycorrhizae and plant growth promoting rhizobacteria (PGPR) in improving crop productivity under stressful environments. Biotech. Adv. 32:429-48. .

Nasim, W., Ahmad, A., Wajid, A., Akhtar, J. and Muhammad, D. 2011. Nitrogen effects on growth and development of sunflower hybrids under agroclimatic conditions of Multan. Pak. J. Bot. 43:2083-2092.

Obour, A. K., Mikha, M. M., Holman, J. D. and Stahlman, P. W. 2017. Changes in soil surface 
chemistry after fifty years of tillage and nitrogen fertilization. Geoderma 308:46-53.

Osman, E. B. A. and Awed, M. M. M. 2010. Response of sunflower (Helianthus annuus L.) to phosphorus and nitrogen fertilization under different plant spacing at New Valley. Assiut Univ. Bull. Environ. Res. 13(1): 11-19.

Sarkar, R. K. and Mallick, R. B. 2009. Effect of nitrogen, sulphur and foliar spray of nitrate salts on performance of Spring sunflower (Helianthus annuus). Indian J. Agric. Sci. 79:986-990.
Shah, A. H. and Khanday, B. A. 2005. Response of sunflower (Helianthus annuus L.) to nitrogen and phosphours under Kashmir vally conditions. SKUAST J. Res. 7:214-218.

Sharma, K. N. and Namdeo, K. N. 1999. Effect of biofertilizers and phosphorus on growth and yield of soybean (Glycine max L.). Crop Research Hisar $17(2): 160-163$.

USDA 2008. Oil seed situation and outlook. USDA Foreign Agricultural Service (FAS). http://www.fas.usda.gov.

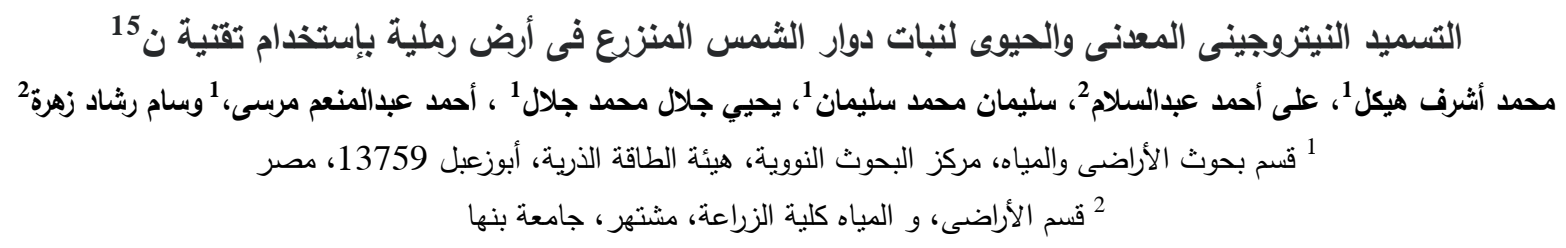

